Arc. Com. Health • Agustus 2021

p-ISSN 2302-139X e-ISSN 2527-3620

Vol. 8 No. 2: 343 - 359

\title{
ANALISIS JALUR FAKTOR-FAKTOR YANG MEMENGARUHI KEGEMUKAN BALITA DI KOTA DENPASAR TAHUN 2020
}

\author{
Angela Yunita Tanggu Bore, Desak Nyoman Widyanthini* \\ Program Studi Sarjana Kesehatan Masyarakat Fakultas Kedokteran Universitas Udayana \\ Jalan PB. Sudirman, Denpasar, Bali 80232
}

\begin{abstract}
ABSTRAK
Kota Denpasar memiliki prevalensi balita gemuk tertinggi di Bali, yaitu sebesar 10,5\%. Balita gemuk berisiko menderita penyakit degenaratif ketika beranjak dewasa. Tujuan penelitian ini untuk mengetahui faktorfaktor yang memengaruhi kegemukan balita di Kota Denpasar. Penelitian ini merupakan penelitian survey analitik dengan rancangan cross-sectional study. Sampel penelitian adalah ibu yang memiliki bayi usia $24-59$ bulan dan tinggal di Kota Denpasar sebanyak 120 sampel yang dipilih secara Convenient Sampling. Variabel yang diteliti yaitu aktivitas fisik, screen time, kebiasaan makan balita, pengetahuan dan sikap ibu yang dikumpulkan menggunakan kuesioner online dan dianalisis menggunakan analisis jalur. Hasil penelitian ini menunjukan bahwa kegemukan balita secara langsung dipengaruhi kebiasaan makan dengan loading factor sebesar $-0,096$ dan secara tidak langsung dipengaruhi screen time melalui aktivitas fisik dengan loading factor sebesar -0,054; dan sikap ibu melalui screen time, aktivitas fisik, dan kebiasaan makan dengan loading factor sebesar 0,079. Aktivitas fisik balita menunjukkan loading factor terbesar, yaitu sebesar 0,214, tetapi tidak bermakna secara statistik. Pengetahuan ibu tidak memengaruhi kegemukan balita dengan loading factor sebesar -0,009. Upaya yang dapat dilakukan bagi orangtua adalah memperbaiki pemahaman mengenai screen time, kebiasaan makan, dan sikap ibu dalam menyikapi perilaku anaknya.
\end{abstract}

Kata Kunci: Kegemukan Balita, Analisis Jalur, Aktivitas Fisik, Screen Time, Sikap Ibu

\begin{abstract}
Denpasar City has the highest prevalence of toodler's overweight in Bali, which is 10,5\%. Toodlers with overweight are at risk of suffering from degenerative diseases when they grow up. The purpose of this study is to determine the factors that influencing toodler's overweight in Denpasar City. This research is an analytic survey with cross-sectional study. Sample of this research is mothers who have babies aged 24-59 months and live in Denpasar City which is 120 sample that selected by Convenient Sampling. Variables of this research are physical activity, screen time, toddler's eating habits, mother's knowledge and attitudes which were collected using an online questionnaire and analyzed using path analysis. The result showed that overweight toddlers are directly affected by eating habits with loading factor 0,096 and indirectly affected by screen time through physical activity $-0,054$; eating habits through physical activity 0,096; and maternal attitudes through screen time, physical activity, and eating habits 0,079. Toddler's physical activity provides the greatest loading factor which is 0,214 , but not significant. Mother's knowledge doesn't affect toddler's overweight with loading factor is $-0,009$. Parents are suggested to improve understanding of toddler's screen time and eating habits, and mother's attitude in responding to their children's behaviour.
\end{abstract}

Key Words: Toddlers Overweight, Path Analysis, Physical Activity, Screen Time, Mother's Attitude

\section{PENDAHULUAN}

Masalah kesehatan gizi pada balita merupakan masalah kesehatan double burden yang tidak hanya mencakup gizi kurang tetapi juga gizi lebih (WHO, 2014). Gizi lebih dapat menyebabkan kelebihan berat badan yang berujung kegemukan atau obesitas (Harjatmo, et al., 2017). Kegemukan adalah suatu kondisi kelebihan akumulasi lemak di dalam tubuh yang akan menimbulkan

*e-mail korespondensi : desakwidyanthini@gmail.com 
masalah kesehatan (WHO, 2014). Menurut WHO (2018), prevalensi balita gemuk dan obesitas terus mengalami peningkatan tiap tahunnya. Prevalensi balita gemuk dan obesitas di dunia tahun 1990 berkisar 32 juta jiwa $(4,8 \%)$ dan meningkat di tahun 2015 menjadi 41 juta jiwa (6,2\%). Hampir setengah dari prevalensi balita gemuk bertempat tinggal di Asia dan Amerika dengan peningkatan $30 \%$ prevalensi kegemukan terjadi di negara berkembang dibandingkan negara maju, salah satunya Indonesia (WHO, 2018).

Berdasarkan Riskesdas 2018, prevalensi balita gemuk di Indonesia tahun 2017 sebesar 4,6\% dan mengalami peningkatan dua kali lipat di tahun 2018 sebesar $8,0 \%$. Bali merupakan salah satu provinsi di Indonesia yang berisiko mengalami peningkatan prevalensi kegemukan pada balita. Prevalensi balita gemuk di Bali tahun 2018 sebesar 7,9\% dan besar prevalensi tersebut hampir sama dengan prevalensi nasional (Kementerian Kesehatan RI, 2018b). Data hasil Pemantauan Status Gizi Balita (PSG) tahun 2017 yang dilakukan pada beberapa provinsi di Indonesia menunjukkan bahwa Bali menempati urutan kedua balita gemuk menurut indeks BB/TB, yaitu sebesar $8,1 \%$. Prevalensi balita gemuk tersebut berada di atas rata-rata nasional yang sebesar 4,6\% (Kementerian Kesehatan RI, 2018a).

Berdasarkan hasil Pemantauan Status Gizi (PSG) tahun 2017, Kota Denpasar merupakan kabupaten/kota dengan prevalensi balita gemuk tertingi di Bali menurut indeks $\mathrm{BB} / \mathrm{TB}$, yaitu sebesar $10,5 \%$.
Laporan hasil operasi timbang berdasarkan indeks BB/TB di seluruh Posyandu Kota Denpasar tahun 2018 menunjukkan jumlah balita yang mengalami kegemukan sebanyak 430 jiwa. Namun data hasil survey status gizi yang dilaksanakan pada beberapa Posyandu di Kota Denpasar tahun 2019 menunjukkan jumlah balita gemuk berumur $0-2$ tahun sebesar 48 jiwa, sedangkan balita berumur 2 - 5 tahun yang mengalami kegemukan sebesar 238 jiwa (Dinas Kesehatan Kota Denpasar, 2018).

Balita diperkirakan mengalami kenaikan berat badan drastis pada usia antara 2 - 6 tahun dan berisiko mengalami obesitas berkelanjutan (Geserick, et al., 2018). Menurut Thorpe dalam Suriani (2019), dampak kegemukan pada balita dibedakan menjadi jangka pendek dan jangka panjang. Risiko jangka pendek dari kegemukan pada balita adalah keterlambatan pertumbuhan, sedangkan risiko jangka panjang kegemukan meliputi hipertensi, diabetes, penyakit kardiovaskuler, dan penyakit degeneratif lainnya saat menginjak usia dewasa. Dampak serius kegemukan pada balita memerlukan perhatian khusus terutama dalam mengidentifikasi penyebab kegemukan tersebut.

Kegemukan yang terjadi pada balita dapat dipengaruhi oleh beberapa faktor yang divisualisasikan dalam bentuk Ecological Model of Child Overweight oleh Davison \& Birch (2001). Model tersebut menunjukkan bahwa kegemukan balita disebabkan oleh beberapa faktor, yaitu karakteristik dan gaya hidup anak, pola asuh dan karakteristik keluarga, serta karakteristik masyarakat dan 
demografi yang divisualisasi dalam bentuk lapisan. Lapisan-lapisan tersebut menunjukkan pengaruh masing-masing faktor risiko terhadap kegemukan balita baik secara langsung maupun tidak langsung, dimana lapisan kedua memengaruhi lapisan pertama, lapisan ketiga memengaruhi lapisan kedua, dan seterusnya (Davison \& Birch, 2001). Lapisan pertama merupakan faktor karakteristik anak dan gaya hidup seperti tingkat konsumsi makanan tinggi lemak dan kurangnya aktivitas fisik (sedentary behavior) seperti bermain dan berolahraga (WHO, 2019). Kurangnya aktivitas fisik merupakan salah satu faktor risiko yang menyebabkan peningkatan kegemukan hingga obesitas pada balita dan anak-anak (WHO, 2019). WHO memberikan rekomendasi kepada orang tua balita dan anak-anak untuk mengatur waktu melakukan aktivitas fisik, perilaku sedentari, dan waktu tidur guna mengurangi risiko obesitas dan penyakit tidak menular yang akan dialami ketika dewasa. Anjuran waktu aktivitas fisik yang dilakukan oleh balita 2459 bulan adalah minimal 180 menit/hari (WHO, 2019).

Hasil penelitian yang dilakukan di Kota Semarang menunjukkan sebanyak 68,9\% balita gemuk memiliki aktivitas fisik kurang dibandingkan balita non-gemuk yang melakukan aktivitas fisik cukup. Penelitian tersebut juga menunjukkan balita yang memiliki aktivitas fisik kurang berisiko 3,63 kali mengalami kegemukan (Syahidah, 2017). Umumnya, aktivitas fisik yang kurang dipengaruhi oleh perilaku sedentari yang tinggi sehingga menyebabkan kegemukan.
Perilaku sedentari merupakan perilaku yang dilakukan saat sadar dan memiliki tingkat pengeluaran energi sangat rendah, seperti kegiatan menghabiskan waktu depan layar elektronik (screen time), duduk, atau berbaring (WHO, 2014). Menurut Davison dan Birch (2001), anak-anak yang menghabiskan waktu menonton TV seharusnya dapat menggunakan waktu tersebut untuk melakukan aktivitas fisik yang dapat mengeluarkan energi.

Seiring perkembangan jaman, balita turut menjadi sasaran kemajuan teknologi yang tampak pada peluncuran beragam permainan dan pendidikan berbasis gadget (Unicef, 2017). Orang tua yang sibuk bekerja juga menggunakan gadget sebagai alat babysitter yang dapat menjaga balita untuk tetap tenang (Sundus, 2017). Balita yang telah terdistraksi kemajuan teknologi memilih menghabiskan waktunya di depan layar elektronik (screen time). Screen time tampak ketika balita menghabiskan waktu menonton TV, main game di komputer atau gadget dan penggunaan komputer untuk kepentingan lainnya (WHO, 2014). Menurut WHO (2019), screen time balita berumur 2 - 5 tahun dibatasi kurang dari satu jam per hari. Namun, hasil penelitian terhadap balita di Semarang tahun 2016 menunjukkan bahwa $86,3 \%$ balita gemuk melakukan screen time $\geq$ 2 jam/hari, sedangkan balita non-gemuk hanya $37,9 \%$. Hasil penelitian tersebut juga menunjukkan balita dengan screen time $\geq 2$ jam berisiko 10,2 kali lebih besar untuk mengalami kegemukan (Syahidah, 2017).

Faktor lainnya yang secara tidak langsung memengaruhi kegemukan balita 
berasal dari keluarga terutama ibu sebagai orang terdekat yang dibuktikan oleh beberapa penelitian. Faktor ibu yang secara tidak langsung memengaruhi kegemukan balita terdiri dari sikap ibu sehubungan dengan perilaku pola makan anak (Tzou \& Chu, 2012; Maxson \& Mitchell, 2016); aktivitas fisik anak (Liszewska et al., 2018; Brouwer et al., 2018); dan sedentary time anak (Sigmund, et al., 2018; He, Piché, Beynon, \& Harris, 2010). Sikap ibu dipengaruhi oleh pengetahuan ibu mengenai pola hidup anak yang sehat dan tepat (Gadsden, Ford, \& Breiner, 2016). Pengetahuan yang baik dan sikap positif ibu akan memengaruhi perilaku balita dalam melakukan aktivitas fisik yang cukup, berkurangnya sedentary time, dan konsumsi makanan sehat.

Berdasarkan pemaparan di atas, telah banyak penelitian yang mencari faktor-faktor yang memengaruhi kegemukan balita, tetapi penelitian tersebut menggunakan metode linear, padahal terdapat kemungkinan hubungan antar faktor (inter-relationship). Oleh karena itu, peneliti menggunakan analisis jalur untuk meneliti faktor-faktor yang memengaruhi kegemukan balita. Model analisis jalur penelitian ini memperkirakan bahwa kegemukan balita di Kota Denpasar dipengaruhi secara langsung oleh aktivitas fisik dan kebiasaan makan, serta secara tidak langsung melalui screen time, pengetahuan dan sikap ibu.

\section{METODE PENELITIAN}

Penelitian ini merupakan penelitian survey analitik dengan rancangan cross-sectional study untuk mengetahui faktor-faktor yang memengaruhi kegemukan balita di Kota Denpasar menggunakan analisis jalur. Penelitian ini dilakukan sejak Januari-Juni 2020. Penelitian ini telah sesuai kaidah etik penelitian dan dinyatakan lulus ethical clearance oleh Komisi Etik Penelitian Litbang FK Unud/RSUP Sanglah dengan nomor 1372/UN14.2.2.VII.14/LT/2020.

Populasi target dalam penelitian ini adalah seluruh balita berusia 24-59 bulan, sedangkan populasi terjangkau adalah seluruh balita berusia 24 - 59 bulan yang bertempat tinggal di Kota Denpasar. Sampel penelitian ini adalah ibu dengan unit analisis balita berusia 24-59 bulan yang bertempat tinggal di Kota Denpasar. Kriteria inklusi penelitian ini adalah ibu yang memiliki balita berusia $24-59$ bulan dan bertempat tinggal di wilayah Kota Denpasar. Kriteria eksklusi penelitian ini adalah balita berusia 24-59 bulan yang memiliki riwayat infeksi seperti diare, malaria, muntahmuntah, batuk, pilek TBC, dan campak dalam satu bulan terakhir. Besar sampel minimal penelitian ini adalah 120 sampel yang diambil menggunakan teknik Convenient Sampling dikarenakan adanya pandemi Covid-19. Convenient Sampling dilakukan tanpa sistematika pengambilan sampel tertentu dimana sampel diambil berdasarkan pertimbangan peneliti yang disesuaikan dengan kriteria inklusi dan eksklusi yang telah ditentukan.

Peneliti mencari responden melalui sosial media seperti LINE, WhatsApp, Instagram, dan sebagainya dengan mencantumkan kriteria ibu yang dijadikan 
responden. Kemudian orang-orang yang melihat pencarian tersebut dan memiliki kenalan ibu sesuai kriteria memberikan kontak personal ibu. Selanjutnya peneliti menghubungi ibu, menjelaskan penelitian secara singkat, dan menanyakan kesediaan untuk menjadi sampel penelitian kemudian memberikan kuesioner online kepada ibu.

Penelitian ini menggunakan data primer yang dikumpulkan menggunakan kuesioner online yang disusun dalam aplikasi kobotoolbox. Instrumen penelitian ini telah diuji coba kepada 132 responden. Kuesioner memuat pertanyaan mengenai aktivitas fisik, screen time, dan kebiasaan makan pada balita, pengetahuan dan sikap ibu, serta karakteristik ibu dan balita. Kuesioner yang digunakan terdiri dari kuesioner Early Years Physical Activity (EY-PAQ), screen time, Food Frequency Questionnaire (FFQ), pengetahuan dan ibu. Kuesioner EY-PAQ merupakan kuesioner aktivitas selama 7 hari yang menggambarkan kebiasaan aktivitas fisik balita, baik kegiatan aktif maupun sedentary dalam lingkungan rumah. Kuesioner screen time merupakan kuesioner recall kegiatan balita dalam menggunakan media elektronik seperti TV, gadget, dan sejenisnya selama 1x24 jam. Kuesioner FFQ merupakan kuesioner yang menggambarkan frekuensi konsumsi makanan balita dalam sehari. Kuesioner pengetahuan ibu menggambarkan pengetahuan ibu tentang aktivitas fisik, screen time, dan konsumsi makanan balita. Kuesioner sikap ibu menggambarkan bagaimana ibu menyikapi beberapa pernyataan berkaitan dengan tentang aktivitas fisik, screen time, dan konsumsi makanan balita. Kuesioner online juga menanyakan berat badan dan tinggi badan balita yang diisi oleh ibu, tanpa dilakukan pemeriksaan langsung. Ibu menjawab berat badan dan tinggi badan balita berdasarkan ingatan ibu ketika melakukan kunjungan posyandu atau puskesmas terakhir.

Data yang terkumpul dianalisis secara univariat untuk mendapatkan gambaran distribusi dan frekuensi dari variabel bebas dan variabel tergantung. Hasil analisis univariabel akan disajikan dalam tabel distribusi tunggal dengan menyertakan nilai frekuensi relatif dan persentase untuk data skala pengukuran kategorikal, penyajian distribusi rerata (mean) dan standar deviasi (SD) untuk data skala pengukuran numerik yang berdistribusi normal, serta penyajian median dan interquartile range (IQR) untuk data numerik tidak berdistribusi normal. Selanjutnya, melihat faktor yang berpengaruh secara langsung maupun tidak langsung terhadap kegemukan balita menggunakan analisis jalur. Faktor tersebut antara lain aktivitas fisik, screen time, kebiasaan makan, pengetahuan dan sikap ibu.

\section{HASIL}

\section{Karakteristik Sampel}

Sampel yang terkumpul pada penelitian ini sebanyak 132 orang yang telah memenuhi kriteria inklusi dan eksklusi penelitian. Karakteristik sampel penelitian ini dibagi menjadi karakteristik balita dan ibu. Karakteristik balita terdiri dari umur dan jenis kelamin, sedangkan karakteristik 
ibu terdiri dari umur, pendidikan terakhir, pekerjaan ibu, dan pendapatan keluarga.

Tabel 1. Karakteristik Balita dan Ibu

\begin{tabular}{lr}
\hline \multicolumn{1}{c}{ Karakteristik } & $\mathbf{n}=\mathbf{1 3 2}$ \\
\hline Umur Balita dalam bulan (mean, SD) & $39,19(11,21)$ \\
Jenis Kelamin Balita (n; \%) & $74(56,06)$ \\
$\quad$ Laki-Laki & $58(43,94)$ \\
$\quad$ Perempuan & $31,98(5,23)$ \\
Umur Ibu dalam tahun (mean, SD) & \\
Pendidikan Terakhir Ibu (n, \%) & $13(9,85)$ \\
$\quad$ Menengah (SD dan SMP) & $51(38,64)$ \\
$\quad$ Atas (SMA) & $68(51,52)$ \\
Tinggi (Diploma/Sarjana) & \\
Pekerjaan Ibu (n, \%) & $1(0,76)$ \\
$\quad$ Pedagang & $2(1,52)$ \\
$\quad$ Buruh/Tani & $9(6,62)$ \\
$\quad$ PNS & $32(24,24)$ \\
Wiraswasta & $62(46,97)$ \\
IRT & $26(19,70)$ \\
Lainnya & \\
Pendapatan Keluarga/Bulan (n, \%) & \\
$\quad$ Rendah (< Rp. 2.553.000 UMK Kota & $33(25,00)$ \\
Denpasar) & \\
Tinggi ( $\geq$ Rp. 2.553.000 UMK Kota & $99(75,00)$ \\
Denpasar) & \\
\hline
\end{tabular}

Tabel 1 menunjukkan bahwa rerata umur balita adalah 39 bulan dan lebih dari setengah balita berjenis kelamin laki-laki $(56,06 \%)$. Selain itu, tabel tersebut juga menunjukkan bahwa rerata umur ibu adalah 31 tahun, ibu memiliki pendidikan terakhir terbanyak adalah diploma/sarjana (51,52\%), dengan jenis pekerjaan paling banyak adalah tidak bekerja/IRT (46,97\%), dan sebagian besar keluarga memiliki pendapatan per bulan tinggi

(75\%).

Tabel 2. Status Gizi Balita Menurut BB/TB

\begin{tabular}{lcc}
\hline \multicolumn{1}{c}{ Status Gizi Menurut BB/TB } & $\begin{array}{c}\text { Frekuensi } \\
(\mathbf{n = 1 3 2 )}\end{array}$ & $\begin{array}{c}\text { Persentase } \\
(\mathbf{\%})\end{array}$ \\
\hline $\begin{array}{l}\text { Status Gizi } \\
\text { Gizi Baik/Normal (Z-score : - 2 SD s.d +1 }\end{array}$ & 62 & 46,97 \\
$\quad$ SD) & & 18,94 \\
$\quad \begin{array}{l}\text { Berisiko Kegemukan (Z-score : > +1 SD } \\
\text { s.d +2 SD) }\end{array}$ & 25 & 34,09
\end{tabular}

*e-mail korespondensi : desakwidyanthini@gmail.com 
Arc. Com. Health • Agustus 2021

p-ISSN 2302-139X e-ISSN 2527-3620

Vol. 8 No. 2: 343 - 359

\begin{tabular}{cccccc} 
Total & & & 132 & 100 \\
\hline Tabel 2 menunjukkan bahwa dengan & status gizi berisiko kegemukan
\end{tabular}
persentase ibu memiliki balita dengan status gizi normal sebesar 46,97\%, sedangkan balita kegemukan sebesar 34,09\%.

Tabel 3. Gambaran Faktor-Faktor yang Memengaruhi Kegemukan Balita

\begin{tabular}{lcc}
\hline \multicolumn{1}{c}{ Variabel } & F (\%) & Rerata (SD) \\
\hline Aktivitas Fisik Balita & $37(28,03)$ & $122,17(170,75)$ \\
$\quad$ Kurang & $95(71,97)$ & menit/hari \\
$\quad$ Cukup & $92(69,70)$ & $208,53(133,73)$ \\
Screen Time Balita & menit/hari \\
High Screen Time & $40(30,30)$ & \\
Low Screen Time & & \\
Kebiasaan Makan & $20 ; 2($ median; IQR) & \\
Pengetahuan Ibu & & $66,21(16,94)$ \\
Kurang & $48(36,36)$ & \\
Cukup & $50(37,88)$ & $26,59(3,42)$ \\
Baik & $34(25,76)$ & \\
Sikap Ibu & & \\
Negatif & $66(50,00)$ & \\
Positif & $66(50,00)$ & \\
\hline
\end{tabular}

Tabel 3 menunjukkan sebagian besar balita memiliki aktivitas fisik yang cukup (71,97\%) dengan rerata waktu sebesar 122,17 menit/hari. Balita memiliki waktu menatap layar elektronik yang tinggi $(69,70 \%)$ dengan rerata waktu 208,53 menit/hari. Nilai tengah kebiasaan makan balita sebesar 20 kali/hari untuk 7 jenis makanan. Tabel tersebut juga menunjukkan bahwa ibu memiliki pengetahuan kurang tentang aktivitas fisik, screen time, dan kebiasaan makan (45,45\%) dengan rerata skor 66,21, serta persentase sikap positif dan negatif ibu yang sama besar terhadap perilaku anaknya (50\%) dengan rerata skor 26,59 .

Faktor-Faktor Pengaruh Kegemukan Balita analisis jalur faktor-faktor yang memengaruhi kegemukan balita di Kota Denpasar. Berdasarkan hasil analisis menunjukkan model analisis jalur untuk mengukur efek langsung, tidak langsung, dan total efek dari aktivitas fisik, screen time, kebiasaan makan balita, serta pengetahuan dan sikap ibu terhadap kegemukan balita fit dengan data (Chi-square >0,05; RMSEA < $0,08)$. 


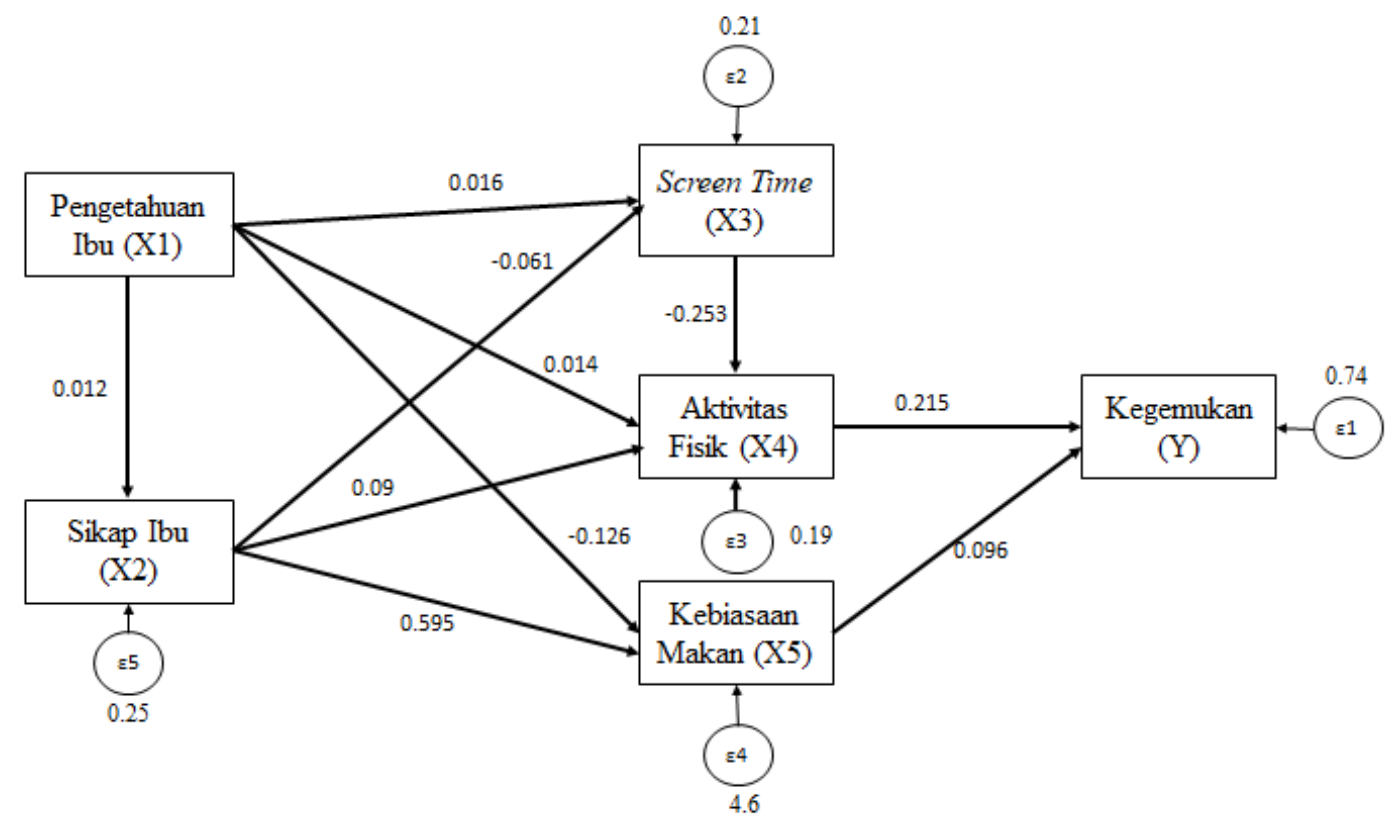

Gambar 1. Model Analisis Jalur Faktor-Faktor yang Memengaruhi Kegemukan Balita di Kota Denpasar

Berdasarkan hasil analisis pada tabel 4, faktor langsung yang memengaruhi kegemukan balita secara signifikan adalah kebiasaan makan dimana kebiasaan makan memberikan efek sebesar $9,6 \%$ terhadap kegemukan balita. Aktivitas fisik memberikan efek sebesar 21,4\% terhadap kegemukan tetapi tidak signifikan secara statistik.

Tabel 4 juga menunjukan bahwa screen time memberikan efek tidak langsung yang berlawanan terhadap kegemukan melalui aktivitas fisik balita, yaitu sebesar 5,4\% dan signifikan secara statistik. Sikap ibu memberikan efek tidak langsung terhadap kegemukan melalui screen time sebesar 0,3\%, aktivitas fisik sebesar 1,9\%, dan kebiasaan makan sebesar 5,7\%. Besar total efek sikap ibu terhadap kegemukan balita, yaitu 7,9\% dan signifikan secara statistik.

Kegemukan balita juga dipengaruhi secara tidak langsung oleh pengetahuan ibu melalui sikap ibu sebesar $0,1 \%$ dan aktivitas fisik sebesar 0,3\%. Selain itu, pengetahuan ibu memberikan efek yang berlawanan terhadap kegemukan balita melalui screen time sebesar 0,1\% dan kebiasaan makan sebesar 1,2\%. Besar total efek pengetahuan ibu terhadap kegemukan balita, yaitu $-0,9 \%$ tetapi tidak signifikan secara statistik. 


\section{Tabel 4. Analisis Jalur Faktor-Faktor yang Memengaruhi Kegemukan Balita}

\begin{tabular}{|c|c|c|c|}
\hline Faktor Pengaruh & Efek & Total Efek & p Value \\
\hline $\begin{array}{l}\text { Aktivitas fisik terhadap kegemukan } \\
\text { balita }\end{array}$ & 0,214 & 0,214 & 0,198 \\
\hline $\begin{array}{l}\text { Kebiasaan makan terhadap kegemukan } \\
\text { balita }\end{array}$ & 0,096 & 0,096 & $0,005^{*}$ \\
\hline Screen time terhadap aktivitas fisik balita & $-0,054$ & $-0,054$ & $0,002^{*}$ \\
\hline Sikap ibu terhadap screen time balita & 0,003 & & \\
\hline Sikap ibu terhadap aktivitas fisik balita & 0,019 & 0,079 & $0,043^{*}$ \\
\hline $\begin{array}{l}\text { Sikap ibu terhadap kebiasaan makan } \\
\text { balita }\end{array}$ & 0,057 & & \\
\hline Pengetahuan ibu terhadap sikap ibu & 0,001 & & \\
\hline $\begin{array}{l}\text { Pengetahuan ibu terhadap screen time } \\
\text { balita }\end{array}$ & $-0,001$ & & \\
\hline $\begin{array}{l}\text { Pengetahuan ibu terhadap aktivitas fisik } \\
\text { balita }\end{array}$ & 0,003 & $-0,009$ & 0,732 \\
\hline $\begin{array}{l}\text { Pengetahuan ibu terhadap kebiasaan } \\
\text { makan balita }\end{array}$ & $-0,012$ & & \\
\hline
\end{tabular}

\section{DISKUSI}

Hasil penelitian ini menunjukkan bahwa persentase balita yang mengalami kegemukan di Kota Denpasar sebesar $34,09 \%$. Persentase kegemukan tersebut dapat dikatakan cukup tinggi dan melebihi prevalensi kegemukan balita di Bali tahun 2018, yaitu sebesar 7,9\%. Hal ini bisa dipengaruhi oleh dua faktor, yaitu selection bias dan kriteria pengkategorian status gizi balita terbaru. Selection bias penelitian ini bisa terjadi ketika penyebaran kuesioner online lebih banyak direspon oleh ibu yang memiliki balita gemuk karena kesalahpahaman judul penelitian, sehingga ibu-ibu mengira bahwa yang boleh mengisi kuesioner hanya ibu yang memiliki balita gemuk. Selain itu, penilaian status gizi terbaru yang diatur dalam Peraturan Menteri Kesehatan RI No. 2 Tahun 2020 lebih sensitif dalam mengidentifikasi kegemukan balita dengan rentang Z-score yang lebih luas dibandingkan Peraturan Menteri Kesehatan RI Tahun 2010.

Berdasarkan model analisis jalur menunjukkan aktivitas fisik memiliki pengaruh langsung terhadap kegemukan balita sebesar $21 \%$, tetapi tidak bermakna secara statistik karena kemungkinan 
dipengaruhi oleh besar sampel. Hasil penelitian ini sesuai dengan teori Ecological Model of Child Overweight yang menyatakan bahwa anak dengan aktivitas fisik yang rendah dan jarang berolahraga memiliki IMT lebih tinggi, ketebalan kulit lebih besar, massa lemak lebih besar, dan berstatus obesitas (Davison \& Birch, 2001).

Aktivitas fisik yang dapat dilakukan balita dikelompokkan menjadi aktivitas ringan dan aktivitas sedang-berat. Aktivitas fisik ringan (Light-Intensity Physical Activity) untuk anak-anak seperti berjalan, mandi, atau aktivitas tidak disengaja lainnya yang tidak menyebabkan anak berkeringat atau kesusahan bernapas. Aktivitas fisik sedangberat (Moderate to Vigorous Intensity Physical Activity) untuk anak-anak seperti jalan cepat, bersepeda, berlari memainkan bola, berenang, menari, dan sebagainya yang menyebabkan anak berkeringat dan kesusahan bernapas. Anak berumur 2-5 tahun disarankan untuk melakukan aktivitas fisik ringan minimal 180 menit/hari yang diantaranya melakukan aktivitas fisik sedang-berat 60 menit/hari (WHO, 2019).

Hasil penelitian ini sejalan dengan penelitian yang dilakukan oleh Nudhira, Wekadigunawan, \& Murti, (2017) di Surakarta yang menunjukkan bahwa balita dengan aktivitas fisik yang cukup dapat mengurangi risiko kegemukan. Penelitian yang dilakukan oleh Syahidah (2017) juga menunjukkan hasil serupa bahwa balita yang memiliki aktivitas fisik kurang berisiko mengalami kegemukan 3,63 kali lebih besar dibandingkan balita dengan aktivitas fisik cukup. Hasil penelitian ini menunjukkan bahwa 71,97\% balita melakukan aktivitas fisik cukup yang sesuai dengan anjuran WHO yaitu minimal 180 menit/hari melakukan kegiatan ringan atau sedang hingga berat.

Kegiatan balita menatap layar elektronik (screen time) memengaruhi kegemukan secara tidak langsung melalui aktivitas fisik efek sebesar -5,4\%. Hasil penelitian ini sejalan dengan teori Ecological Model of Predictors of Childhood Overweight oleh Davison \& Birch (2001) yang menyatakan bahwa screen time merupakan salah satu kegiatan sedentary time yang memengaruhi kegemukan balita secara tidak langsung. Teori tersebut sejalan dengan penelitian yang dilakukan oleh Thomas, et al., (2017) bahwa orangtua perlu mengurangi kegiatan screen time seperti menonton TV, bermain video game, dan komputer karena dapat menurunkan kenaikan berat badan anak sehubungan dengan kurangnya aktivitas fisik.

Balita yang melakukan screen time tinggi akan diikuti dengan berkurangnya aktivitas fisik yang berujung pada kenaikan berat badan (Magriplis, Farajian, Panagiotakos, Risvas, \& Zampelas, 2019). Hal ini sejalan dengan hasil penelitian analisis jalur bahwa screen time balita signifikan memengaruhi aktivitas fisik balita tersebut dan secara tidak langsung memengaruhi kegemukan sebesar $-5,4 \%$, artinya pengurangan kegiatan screen time membuat balita dapat menghabiskan waktu untuk melakukan kegiatan fisik, yang semestinya dapat membakar kalori tubuh dan dapat mengontrol berat badan balita. 
Hasil penelitian ini menunjukkan bahwa persentase balita yang melakukan Low Screen Time (LST) cukup besar, yaitu sebesar $30,30 \%$. Namun, sebagian besar balita turut melakukan aktivitas fisik yang cukup, yaitu sebesar 71,97\%. Oleh sebab itu, meskipun balita melakukan screen time, balita tetap melakukan aktivitas fisik yang dapat mengeluarkan energi sehingga mengurangi risiko kegemukan.

Kebiasaan makan balita memberikan pengaruh langsung terhadap kegemukan balita sebesar 9,6\% dan signifikan secara statistik. Hasil penelitian ini sejalan dengan penelitian yang dilakukan oleh Istiqomah, Sundari, \& Rika Wulandari (2014) di Yogyakarta. Penelitian analisis jalur yang dilakukan oleh Nudhira, Wekadigunawan, \& Murti (2017) di Surakarta juga menunjukkan bahwa asupan makanan signifikan memengaruhi kegemukan balita sebesar $1,9 \%$.

Berdasarkan Ecological Model of Predictors of Childhood Overweight, kebiasaan makan balita merupakan salah satu perilaku balita yang dapat memengaruhi kegemukan balita. Teori tersebut menyatakan bahwa konsumsi makanan tinggi kalori berhubungan dengan peningkatan ketebalan kulit dan IMT anak (Davison \& Birch, 2001).

Hasil penelitian ini menunjukkan bahwa sebagian besar balita mengonsumsi makanan sumber karbohidrat 3-5 kali/hari (50,76\%) dan Sugar-Sweetened Bevarages (SSB) sebanyak 1-2 kali/hari (61,36\%). Menurut Agostoni et al., (2011), karbohidrat berhubungan dengan perubahan komposisi tubuh sehingga dapat memengaruhi IMT anak. Selain karbohidrat, makanan manis (SSB) berhubungan positif dengan kenaikan berat badan dan obesitas jangka panjang karena SSB memiliki kandungan gizi yang rendah. SSB tidak mengenyangkan perut dan menyebabkan anak mengonsumsi makanan lainnya untuk memenuhi rasa kenyang (Huang \& Qi, 2015).

Pengetahuan ibu bukan merupakan faktor yang memengaruhi kegemukan dengan total efek sebesar 0,9\%. Pengetahuan ibu secara tidak langsung memengaruhi kegemukan balita melalui aktivitas fisik, screen time, dan sikap ibu, tetapi tidak signifikan secara statistik. Hasil penelitian ini sejalan dengan penelitian yang dilakukan oleh Romanos-Nanclares et al., (2018), menyatakan bahwa pengetahuan ibu tentang gizi tidak berhubungan dengan perilaku anak. Hasil yang tidak signifikan dapat disebabkan oleh anak yang sedang dalam masa pertumbuhan dan senang mengeksplor hal-hal baru dengan bergerak aktif di dalam rumah $(43 \%)$ maupun di halaman rumah/kebun (46\%), sehingga anjuran minimal aktivitas fisik balita terpenuhi (71,97\%). Meskipun hasil penelitian menunjukkan bahwa 36,36\% memiliki pengetahuan kurang dan 73,48\% ibu masih belum mengetahui tentang anjuran waktu minimal aktivitas fisik balita dalam satu hari.

Hasil penelitian ini menunjukkan bahwa persentase ibu memiliki pengetahuan kurang sebesar 45,45\%. Berdasarkan hasil analisis jalur, pengetahuan ibu secara tidak langsung memengaruhi kegemukan balita melalui kebiasaan makan dan signifikan secara statistik. Hal ini disebabkan oleh 
ketidakseimbangan pemahaman ibu tentang makanan sehat dan bergizi $(67,42 \%)$ dengan pemberian makanan Sugar-Sweet Beverages (SSB). Sebagian besar balita mengonsumsi makanan jenis SSB (61,36\%) sebanyak 1-2 kali dalam sehari yang berdampak pada peningkatan risiko kegemukan balita. Hasil penelitian ini sejalan dengan penelitian yang dilakukan oleh Yabanc1 et al., (2014) yang menyatakan bahwa pengetahuan ibu memberikan efek positif terhadap kebiasaan makan anak dimana ibu dengan pengetahuan baik akan menyediakan makanan sehat dibandingkan makanan cepat saji kepada anaknya, dan sebaliknya.

Pengetahuan ibu tidak memengaruhi kegemukan melalui screen time karena meskipun $31,06 \%$ ibu memiliki pengetahuan cukup dan 37,12\% diantaranya mengetahui anjuran waktu maksimal menatap layar elektronik untuk balita, ibu tidak membatasi waktu balita menonton TV. Hasil penelitian menunjukkan bahwa $60 \%$ balita menghabiskan waktu duduk menonton TV selama 1 jam. Pengetahuan ibu juga tidak memengaruhi kegemukan balita melalui sikap ibu karena meskipun 31,06\% ibu berpengetahuan cukup dan 23,48\% berpengetahuan baik tentang perilaku balita, $50,00 \%$ ibu memiliki sikap negatif terhadap perilaku balita.

Sikap ibu merupakan faktor yang memengaruhi kegemukan balita dengan total efek sebesar 7,9\%. Hasil analisis menunjukkan bahwa sikap ibu memengaruhi kegemukan secara tidak langsung melalui screen time, aktivitas fisik, dan kebiasaan makan. Hasil ini sejalan dengan penelitian yang dilakukan oleh Solomon-Moore et al., (2017) yang menyatakan bahwa ibu dengan sikap negatif dapat menyebabkan kegiatan screen time meningkat, begitupun sebaliknya.

Berdasarkan Ecological Model of Predictors of Childhood Overweight (Davison \& Birch, 2001), perilaku anak dipengaruhi oleh perilaku dan sikap orangtua. Cara orangtua mengasuh dan melakukan kegiatan screen time akan menjadi contoh anak untuk melakukan hal serupa. Hasil penelitian ini sejalan dengan penelitian yang dilakukan oleh Liszewska et al., (2018), yang menyatakan bahwa sikap orangtua dapat memengaruhi niat anak melakukan aktivitas fisik dan dapat meningkatkan IMT anak.

Sikap ibu memengaruhi kegemukan balita melalui kebiasaan makan karena ibu akan menanggapi apapun yang diinginkan oleh anaknya, tanpa memberikan pengawasan ketat pada makanan yang dikonsumsi. Hal ini dapat dilihat dari persentase konsumsi makanan dimana sebagian besar balita mengonsumsi olahan daging sebanyak 1-2 kali/hari (59,85\%), lemak sebanyak 1-2 kali/hari (52,27\%), dan SSB sebanyak 1-2 kali/hari (61,36\%). Hasil penelitian ini sejalan dengan penelitian yang dilakukan oleh Mohd Hatta et al., (2017) yang menyatakan bahwa orangtua berperan penting dalam menentukan konsumsi makanan anaknya.

Kelemahan penelitian ini terdapat pada pengumpulan data dan instrumen pengumpulan data. Pengumpulan data penelitian ini terkendala kondisi di lapangan akibat Covid-19, sehingga peneliti 
Arc. Com. Health • Agustus 2021

p-ISSN 2302-139X e-ISSN 2527-3620

Vol. 8 No. 2: 343 - 359

menggunakan kuesioner online tanpa wawancara langsung sehingga hasil jawaban kemungkinan terjadi bias informasi. Penelitian ini juga kemungkinan terjadi selection bias karena penyebaran kuesioner secara online dengan judul penelitian yang memfokuskan kepada kegemukan membuat kuesioner lebih banyak diisi oleh ibu-ibu yang memiliki balita gemuk.

Selain itu, kuesioner yang digunakan untuk mengukur pengetahuan dan sikap belum valid sehingga hasil analisis menjadi kurang bagus. Kuesioner FFQ nonkuantitatif yang digunakan belum tepat mengukur pola makan karena tidak menyertakan porsi makanan yang dikonsumsi oleh balita. Variabel status gizi pada penelitian ini juga tidak diukur secara langsung menggunakan instrumen pengukuran yang valid, hanya mengandalkan ingatan responden sehingga kemungkinan bias informasi dapat terjadi.

\section{SIMPULAN}

Berdasarkan hasil analisis penelitian ini, maka dapat disimpulkan bahwa faktor yang secara langsung memengaruhi kegemukan balita di Kota Denpasar adalah kebiasaan makan sebesar 0,096, sedangkan aktivitas fisik memberikan pengaruh terbesar terhadap kegemukan, yaitu sebesar 0,214 tetapi tidak signifikan secara statistik.

Faktor yang secara tidak langsung memengaruhi kegemukan adalah screen time melalui aktivitas fisik dengan total efek 0,054; dan sikap ibu melalui screen time, aktivitas fisik, dan kebiasaan makan dengan total efek 0,079. Pengetahuan ibu tidak memengaruhi kegemukan balita melalui sikap ibu, aktivitas fisik, screen time, dan kebiasaan makan balita dengan total efek sebesar $-0,009$.

\section{SARAN}

Bagi orang tua selaku role model anak dalam keluarga disarankan untuk memperbaiki pemahaman tentang screen time terutama waktu maksimal dalam melakukan screen time. Selain itu, orang tua perlu memperbaiki pemahaman tentang aktivitas fisik balita bahwa balita perlu melakukan aktivitas fisik untuk meningkatkan pertumbuhan dan perkembangan, serta mengurangi risiko kegemukan. Orang tua dapat memperbaiki cara menyikapi perilaku balita mengenai screen time, aktivitas fisik, dan kebiasaan makan balita. Perbaikan pemahaman dapat dilakukan dengan bertanya pada petugas kesehatan ketika kegiatan posyandu atau puskesmas. Orang tua juga dapat memanfaatkan fasilitas taman kota untuk berekreasi sekaligus mengajak anak melakukan kegiatan fisik dan mengurangi penggunaan gadget selama rekreasi.

Penelitian ini memiliki keterbatasan waktu, pengetahuan, dan kondisi yang tidak memungkinkan untuk melakukan penelitian yang tepat. Ada baiknya penelitian dilakukan dengan wawancara menggunakan kuesioner yang valid sehingga tepat mengukur variabel-variabel yang diteliti. Selain itu, disarankan melakukan pengukuran status gizi balita saat kegiatan posyandu atau berdasarkan data terakhir posyandu agar lebih akurat. Instrumen 
untuk mengukur pola makan sebaiknya menggunakan FFQ semi kualitatif dengan terlebih dahulu melakukan studi pendahuluan daftar makanan yang biasanya dikonsumsi oleh bayi berumur 24-59 bulan.

\section{UCAPAN TERIMA KASIH}

Peneliti mengucapkan terima kasih kepada pihak-pihak yang telah membantu sebelum, selama, dan sesudah penelitian ini dilakukan hingga dapat dipublikasikan.

\section{DAFTAR PUSTAKA}

Agostoni, C., Braegger, C., Decsi, T., Kolacek, S., Koletzko, B., Mihatsch, W., ... Van Goudoever, J. (2011). Role of Dietary Factors and Food Habits in The Development of Childhood Obesity: A Commentary by The Espghan Committee on Nutrition. Journal of Pediatric Gastroenterology and Nutrition, $52(6)$, 662-669. https://doi.org/10.1097/MPG.0b013e318 2169253

Brouwer, S. I., Küpers, L. K., Kors, L., Sijtsma, A., Sauer, P. J. J., Renders, C. M., \& Corpeleijn, E. (2018). Parental physical activity is associated with objectively measured physical activity in young children in a sex-specific manner: The GECKO Drenthe cohort. BMC Public Health, 18(1), 1-10. https://doi.org/10.1186/s12889-0185883-x

Davison, K. K., \& Birch, L. L. (2001). Childhood Overweight: A Contextual Model and Recommendations for Future Research. Obesity Reviews, 2(3),
159-171. https://doi.org/10.1046/j.1467789x.2001.00036.x

Dinas Kesehatan Kota Denpasar. (2018). Laporan Kesehatan Tahun 2018. Denpasar.

Gadsden, V. L., Ford, M., \& Breiner, H. (2016). Parenting matters: Supporting parents of children ages 0-8. In Parenting Matters: Supporting Parents of Children Ages 0-8. https://doi.org/10.17226/21868

Geserick, M., Vogel, M., Gausche, R., Lipek, T., Spielau, U., Keller, E., ... Körner, A. (2018). Acceleration of BMI in Early Childhood and Risk of Sustained Obesity. New England Journal of Medicine, 379(14), 1303-1312. https://doi.org/10.1056/NEJMoa1803527 Harjatmo, Holil, Wiyono, S. (2017). Bahan Ajar Gizi (2017th ed.; N. Thamaria, ed.). Jakarta: Kementerian Kesehatan RI.

He, M., Piché, L., Beynon, C., \& Harris, S. (2010). Screen-related Sedentary Behaviors: Children's and Parents' Attitudes, Motivations, and Practices. Journal of Nutrition Education and Behavior, 42(1), 17-25. https://doi.org/10.1016/j.jneb.2008.11.01 1

Huang, J. Y., \& Qi, S. J. (2015). Childhood Obesity and Food Intake. World Journal of Pediatrics, 11(2), 101-107. https://doi.org/10.1007/s12519-0150018-2

Istiqomah, A., Sundari, S., \& Rika Wulandari, H. (2014). Faktor - Faktor Yang Mempengaruhi Obesitas pada Balita. Retrieved from 
http://jurnal.akbiduk.ac.id/assets/doc/1 70223081607-2.pdf

Kementerian Kesehatan RI. (2010). Standar Antropometri Penilaian Status Gizi Anak. Jakarta: Kementerian Kesehatan RI.

Kementerian Kesehatan RI. (2018a). Buku Saku Pemantauan Status Gizi (1st ed.). Jakarta: Kementerian Kesehatan RI.

Kementerian Kesehatan RI. (2018b). Profil Kesehatan Indonesia 2017. Jakarta: Kementerian Kesehatan RI.

Kementerian Kesehatan RI. (2020). Standar Antropometri Anak. https://doi.org/10.1016/j.solener.2019.02 .027

Liszewska, N., Scholz, U., Radtke, T., Horodyska, K., Liszewski, M., \& Luszczynska, A. (2018). Association between Children's Physical Activity and Parental Practices Enhancing Children's Physical Activity: The Moderating Effects of Children's BMI z-Score. Frontiers in Psychology, 8(JAN), $1-9$.

https://doi.org/10.3389/fpsyg.2017.0235 9

Magriplis, E., Farajian, P., Panagiotakos, D. B., Risvas, G., \& Zampelas, A. (2019). The Relationship Between Behavioral Factors, Weight Status and a Dietary Pattern in Primary School Aged Children: The GRECO Study. Clinical Nutrition, 38(1), 310-316. https://doi.org/10.1016/j.clnu.2018.01.01 5

Maxson \& Mitchell. (2016). Parental Control and Overconsumption of Snack Foods in Overweight and Obese Children.
HHS Public Access, 176(1), 139-148. https://doi.org/10.1016/j.physbeh.2017.0 3.040

Mohd Hatta, N. K. B., Rahman, N. A. A., Rahman, N. I. A., \& Haque, M. (2017). Knowledge, attitude and practices among mothers regarding childhood obesity at Kuantan, Malaysia. International Medical Journal, 24(2), 200204.

Nudhira, U., Wekadigunawan, C. S., \& Murti, B. (2017). Path Analysis on Life Course Factors Affecting Overweight and Obesity in Children Aged 2 to 5 Years Old in Surakarta. Journal of Epidemiology and Public Health, 02(03), 267-283.

https://doi.org/10.26911/jepublichealth. 2017.02.03.08

Romanos-Nanclares, A., Zazpe, I., Santiago, S., Marín, L., Rico-Campà, A., \& Martín-Calvo, N. (2018). Influence of parental healthy-eating attitudes and nutritional knowledge on nutritional adequacy and diet quality among preschoolers: The SENDO project. Nutrients, 10(12). https://doi.org/10.3390/nu10121875 Sigmund, E., Sigmundová, D., Badura, P., \& Madarasová Gecková, A. (2018). Health-related Parental Indicators and Their Association with Healthy Weight and Overweight/Obese Children's Physical Activity. BMC Public Health, 18(1), $1-11$. https://doi.org/10.1186/s12889-0185582-7

Solomon-Moore, E., Sebire, S. J., Macdonald- 
Wallis, C., Thompson, J. L., Lawlor, D. A., \& Jago, R. (2017). Exploring parents' screen-viewing behaviours and sedentary time in association with their attitudes toward their young child's screen-viewing. Preventive Medicine Reports, 7, 198-205. https://doi.org/10.1016/j.pmedr.2017.06. 011

Sundus, M. (2017). The Impact of Using Gadgets on Children. Journal of Depression and Anxiety, 07(01), 1-3. https://doi.org/10.4172/21671044.1000296

Suriani, S. (2019). Faktor-Faktor Yang Berhubungan dengan Kegemukan pada Balita di Kelurahan Warnasari Kecamatan Citangkil Kota Cilegon. Faletehan Health Journal, 6(1), 1-10. https://doi.org/10.33746/fhj.v6i1.19

Syahidah, Z. (2017). Perbedaan Aktivitas Fisik, Screen Time, dan Persepsi Ibu Terhadap Kegemukan Antara Balita Gemuk dan Non-Gemuk di Kota Semarang. Journal of Nutrition College, $6(1)$, 11. https://doi.org/10.14710/jnc.v6i1.16886

Thomas N. Robinson, MD, MPH, Jorge A. Banda, PhD, Lauren Hale, PhD, Amy Shirong Lu, PhD, Frances FlemingMilici, PhD, Sandra L. Calvert, PhD, and Ellen Wartella, P. (2017). Screen Media Exposure and Obesity in Children and Adolescents. Pediatrics, 176(1), 139-148. https://doi.org/10.1016/j.physbeh.2017.0 3.040

Tzou, I. L., \& Chu, N.-F. (2012). Parental
Influence on Childhood Obesity: A Review. Health, 04(12), 1464-1470. https://doi.org/10.4236/health.2012.412a 211

Unicef. (2017). How Does the Time Children Spend Using Digital Technology Impact Their Mental Well-being, Social Relationships and Physical Activity? In D. Kardefelt (Ed.), Unicef Office of Research-Innocenti (1st ed., Vol. 2). https://doi.org/10.1080/03004439510601 19

World Health Organization. (2014), "Commission on Ending Childhood Obesity", (WHO Institue), Available: http://www.who.int/endchildhoodobesity/facts/en/ (Accessed: 2020, Januari 15).

World Health Organization. (2018), “Obesity and Overweight", (WHO Institute), Available: https://www.who.int/newsroom/factsheets/detail/obesity-andoverweight\# (Accessed: 2020, Januari 15).

World Health Organization. (2019). WHO Guidelines on Physical Activity, Sedentary Behaviour and Sleep For Children Under 5 Years of Age. In World Health Organization. Retrieved from

https://apps.who.int/iris/bitstream/han dle/10665/325147/WHO-NMH-PND2019.4eng.pdf? sequence $=1 \&$ isAllowed $=y \% 0 A$ http://www.who.int/iris/handle/10665/3 11664\%0Ahttps://apps.who.int/iris/han dle/10665/325147

Yabancı, N., Kısaç, İ., \& Karakuş, S. Ş. (2014). 
Arc. Com. Health Agustus 2021

p-ISSN 2302-139X e-ISSN 2527-3620

Vol. 8 No. 2: 343 - 359

The Effects of Mother's Nutritional

116(February), $4477-4481$.

Knowledge on Attitudes and Behaviors https://doi.org/10.1016/j.sbspro.2014.01. of Children about Nutrition. Procedia 970

Social and Behavioral Sciences, 